\begin{abstract}
Abednego Andhana Prakosajaya, Hot Marangkup Tumpal Sianipar, dan Ayu Nur Widiyastuti Departemen Arkeologi Fakultas IImu Budaya Universitas Gadjah Mada, Jalan Sosiohumaniora, No. 1, Bulaksumur, Yogyakarta 55281, Indonesia; posel: abednego.andhana@mail.ugm.ac.id, hot.marangkup.tumpal@mail.ugm.ac.id ayunur2018@mail.ugm.ac.id
\end{abstract}

Diterima: 14 Juli 2020

Direvisi: 4 Oktober 2020

Disetujui: 7 Oktober 2020

\section{PEMILIHAN LOKASI PABRIK GULA GUNUNGSARI OLEH HANDELSVEREENIGING AMSTERDAM (HVA): ANALISIS KERUANGAN SALAH SATU "SISTER FACTORY" PABRIK GULA JATIROTO}

\begin{abstract}
Abstrak. Pabrik Gula Gunungsari merupakan pabrik gula yang didirikan oleh Handels Vereeniging Amsterdamatau HVA pada awal abad ke-20 Masehi. Pabrik gula yang dimaksudkan untuk menjadi sister factory atau pabrik pendukung dari Pabrik Gula Jatiroto ini merupakan bagian dari rangkaian rencana percobaan HVA dalam merevolusi industri gula di Hindia Belanda. Penelitian bertujuan untuk menganalisis apakah terdapat kesalahan dalam bidang perencanaan pemilihan lokasi pembangunan pabrik gula yang berkaitan dengan berhentinya operasi pabrik gula ini. Metode penelitian bersifat deskriptif dengan penalaran induktif. Data yang dianalisis secara spasial diperoleh dari hasil survei arkeologi di Pabrik Gula Gunungsari dan kajian pustaka. Hasil penelitian menunjukkan bahwa ketergantungan yang sangat tinggi akan besarnya modal usaha serta anggapan dapat terpenuhinya target yang terlalu ambisius menyebabkan pemilihan lokasi pembangunan pabrik menjadi suatu hal yang merugikan bagi HVA sendiri.
\end{abstract}

Kata kunci: Analisis spasial, Pabrik Gula Gunungsari; Handels Vereeniging Amsterdam; Pabrik Gula Jatiroto

\begin{abstract}
Gunungsari Sugar Factory had been established by Handels Vereeniging Amsterdam or HVA in the early of 20th century. The factory which was intended to be a sister of the Jatiroto Sugar Factory was part of a series of HVA trial plans to revolutionize the sugar industry in the Dutch East Indies. This paper aims to analyze whether there is a failure when selecting the location of the factory related to the cessation of its own operation. This method used is descriptive with inductive reasoning. The data analized in spatial were obtained from the survey conducted at the Gunungsari Sugar Factory and literature review. The results show that high dependence on the amount of venture capital, and the assumption that ambitious targets can be achieved, have made the selection of a factory construction location become a major weakness for HVA.
\end{abstract}

Keywords: spatial analysis, Gunungsari Sugar Factory; Handels Vereeniging Amsterdam; Jatiroto Sugar Factory

\section{PENDAHULUAN}

Pabrik Gula Gunungsari yang berlokasi di Desa Kencong, Kecamatan Kencong, Kabupaten Jember kini hanya menyisakan reruntuhan. Akan tetapi, tata ruang dan kondisi lingkungan sekitar pabrik gula ini masih menyisakan data untuk merekonstruksi dasar pemilihan lokasi dibangunnya pabrik gula yang hanya beroperasi kurang dari lima tahun. Pabrik ini beroperasi dari tahun 1928 hingga krisis ekonomi melanda dunia pada tahun 1931. Krisis ini menyebabkan harga gula jatuh dan tentunya membuat industri gula di Jawa hancur (Knight 2013).

Keberadaan Pabrik Gula Gunungsari tidak dapat dilepaskan dari proyek ambisius perusahaan Handels Vereeniging Amsterdam atau HVA yang ingin mengembangkan kawasan Jatiroto dengan membangun perkampungan serta pabrik-pabrik pendukung atau sister factory di sekitar Pabrik Gula Jatiroto (Knight 2013). Pabrik Gula Jatiroto difungsikan sebagai pusat dari kawasan perkebunan gula terpadu. Sementara Pabrik Gula Gunungsari, Semboro, dan Bedadung difungsikan sebagai pabrik gula pendukung. Kawasan dimana keempat pabrik ini berdiri dengan lahan pertanian tebunya memiliki keseluruhan luas kurang lebih 250.000 hektare menjadikan kawasan Jatiroto dengan empat pabrik gulanya sebagai penghasil gula terbesar di Indonesia pada akhir 1920-an (Knight 2013). Dari keempat pabrik ini, Pabrik Gula Semboro dan Pabrik Gula Gunungsari memiliki rancangan yang sangat identik dengan Pabrik Gula Semboro sehingga kedua pabrik ini disebut sebagai pabrik kembar atau tweeling fabrieken. Mengingat uniknya Pabrik Gula Gunungsari dalam berbagai aspek, tulisan ini akan berusaha untuk membahas pemilihan letak Pabrik Gula Gunungsari dalam 
Pemilihan Lokasi Pabrik Gula Gunungsari oleh Handelsvereeniging Amsterdam (HVA): Analisis Keruangan Salah Satu "Sister Factory" Pabrik Gula Jatiroto- Abednego Andhana Prakosajaya, Hot Marangkup Tumpal Sianipar, dan Ayu Nur Widiyastuti (113-124)

Doi: $10.24832 / k e . v 6 i 2.67$

konteks sistem perkebunan terpadu wilayah Jatiroto dan mengetahui apakah terdapat kesalahan dalam aspek keruangan yang mempengaruhi singkatnya masa operasional pabrik gula ini.

\section{METODE}

Penelitian ini menggunakan metode bersifat deskriptif dengan penalaran induktif. Penalaran induktif adalah metode yang dimaksudkan untuk menjelaskan masalah dengan data yang ada. Tujuan dari penalaran ini adalah memperdalam pengetahuan mengenai suatu gejala tertentu atau mendapatkan pengetahuan baru mengenai gejala tersebut. Tahap pengumpulan data merupakan tahapan pertama yang dilakukan (Ginaris 2019). Adapun data dalam penelitian ini diperoleh melalui dua cara, yaitu survei arkeologi dan kajian pustaka. Survei arkeologi adalah pengamatan terhadap tinggalan arkeologi disertai dengan analisis yang dalam. Sedangkan, kajian pustaka adalah studi terhadap data tertulis yang berhubungan dengan tinggalan arkeologi yang akan diteliti, baik dari publikasi arkeologis maupun sumber-sumber sejarah atau sumber lainnya. Selain tertulis, data kepustakaan dapat juga berupa gambar, foto, dan peta (Sukendar 1999). Survei arkeologi dilaksanakan dengan mengadakan kunjungan ke lokasi bekas Pabrik Gula Gunungsari di Desa Kencong, Kecamatan Kencong, Kabupaten Jember. Perolehan data melalui kajian pustaka dilakukan terhadap tiga sumber, yaitu sumber arsip berupa dokumen, sumber arsip berupa peta, dan sumber-sumber lainnya berupa hasil penelitian yang berkaitan dengan permasalahan dalam penelitian ini.

Dari proses kajian pustaka terhadap data arsip dokumen tertulis, diperoleh tiga sumber arsip berupa satu dokumen yang diterbitkan sebelum pabrik gula diresmikan dan dua dokumen saat Pabrik Gula Gunungsari beroperasi. Kajian pustaka dari sumber arsip berbentuk peta berhasil menemukan tiga peta yang membantu peneliti untuk merekonstruksi lingkungan dan tata ruang pabrik gula yang tidak dapat dijumpai di lapangan saat ini. Peta utama yang dijadikan acuan adalah peta tahun 1941, sementara peta Karesidenan Pasuruan tahun 1885 dan peta Karesidenan Besuki tahun 1888 akan dijadikan pertimbangan untuk mengukur perubahan yang dilakukan oleh HVA 114 sebelum Pabrik Gula Gunungsari dan kawasan perkebunan gula di Jatiroto didirikan. Sebagai pertimbangan, penelitian ini juga akan menggunakan hasil citra satelit untuk mempermudah peneliti dalam merangkai konteks lingkungan serta memahami lebih lanjut letak Pabrik Gula Gunungsari dalam kawasan Pabrik Gula Jatiroto.

Selanjutnya, peneliti akan menemukan fenomena dari pemilihan lokasi penempatan Pabrik Gula Gunungsari dalam sistem perkebunan gula Jatiroto yang dipusatkan di Pabrik Gula Jatiroto, berupa sisa-sisa tata ruang yang hingga saat ini masih dapat diamati dan diteliti lebih lanjut di area bekas Pabrik Gula Gunungsari. Data yang telah terkumpul, kemudian diintegrasikan atau dideskripsikan. Dalam proses deskripsi, penjelasan akan terfokus pada temuan fenomena di lapangan kemudian dikaitkan dengan teori berdasarkan sumber-sumber yang telah diperoleh. Setelah data terintegrasi, maka akan tersedia bahan untuk penyimpulan. Hasil penyimpulan inilah yang dianggap sebagai eksplanasi. Tahap eksplanasi akan menghasilkan narasi berdasarkan temuantemuan dan fenomena di lapangan dengan harapan untuk menyusun teori baru dan tidak bersifat mengkritisi teori yang ada.

\section{HASIL DAN PEMBAHASAN}

\section{Sejarah Pabrik Gula Gunungsari}

Pabrik Gula Gunungsari didirikan oleh HVA sebagai pendukung dari Pabrik Gula Jatiroto yang terlebih dahulu beroperasi pada tahun 1910 (Dofi 2016). Berdasarkan arsip Aangeboden Door De Handelsvereeniging "Amsterdam" (HVA) 1 Januari 1929, diketahui bahwa lahan untuk Pabrik Gula Gunungsari dan Pabrik Gula Semboro diperoleh pada bulan April 1925 dan pembangunan dimulai tidak lama setelah lahan diperoleh (Gambar 1). Setelah pembangunan selesai, Pabrik Gula Gunungsari melakukan masa uji coba pada tahun 1927 (Gambar 2) dan sepenuhnya beroperasi pada tahun 1928 bersamaan dengan Pabrik Gula Semboro. Arsip Van Westersch Grootbedrijf menunjukkan bahwa pembangunan Pabrik Gula Gunungsari menelan biaya kurang lebih 12.000 .000 gulden dan dilengkapi dengan jaringan rel lori yang panjangnya mencapai $90 \mathrm{~km}$. Sumber yang sama 
juga menunjukkan bahwa selama beroperasi, Pabrik Gula Gunungsari mampu mengelola 30.000 pikul tebu dengan biaya operasional mencapai 1.500.000 gulden. Saat beroperasi, masa giling pabrik gula ini dimulai pada 30 Mei dan berakhir pada 25 November atau 180 hari kerja (Nurcahyo 2011). Adapun keseluruhan lahan produktif tebu di sekitar pabrik gula ini berjumlah 1.232 hektare (Nurcahyo 2011).

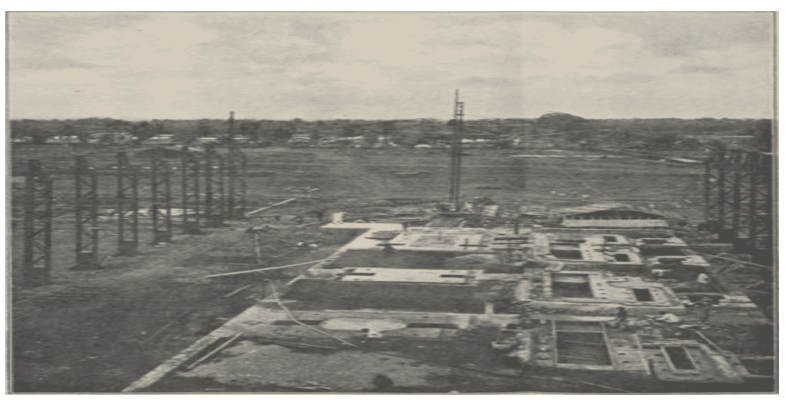

Sumber: Van Westerch Grootbedriff: Overdruk eener serie artikelen uit het Soerabaiasch Handeslblad van 30, 31 Mei, 1, 2, en 3 Juni 1927

Gambar 1 Pembangunan Pabrik Gula Gunungsari pada Oktober 1926

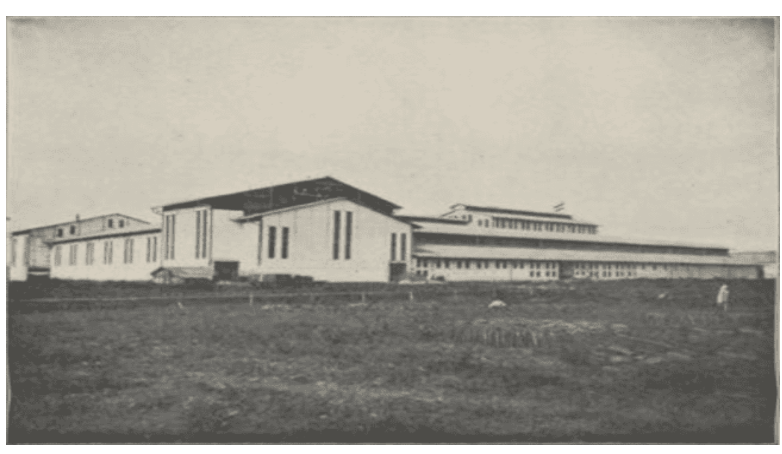

Sumber: Van Westerch Grootbedriff: Overdruk eener serie artikelen uit het Soerabaiasch Handeslblad van 30, 31 Mei, 1, 2, en 3 Juni 1927

Gambar 2 Bangunan Pabrik yang Tampak Siap Beroperasi pada April 1927

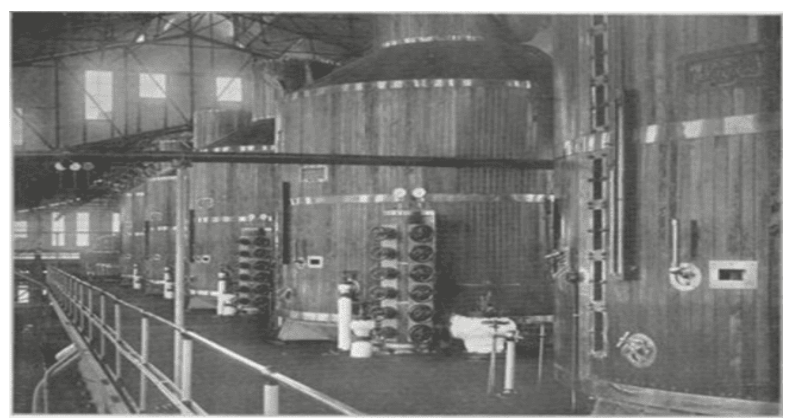

Sumber: Aangeboden Door De Handelsvereeniging "Amsterdam" (HVA) 1 Januari 1929

Gambar 3 Lima Mesin Boiler yang Terelevasi

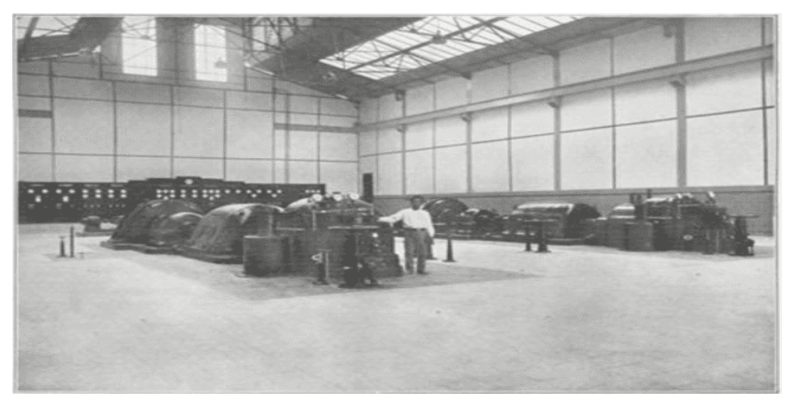

Sumber: Aangeboden Door De Handelsvereeniging

"Amsterdam" (HVA) 1 Januari 1929

Gambar 4 Dua Turbin di ruangan Turbinehuis pada Bagian Tengah Pabrik dengan Dua Pembangkit Listriknya

Berdasarkan arsip Archief voor de Suikerindustrie in Nederlandsch-Indië: Orgaan van het Algemenen Syndicaat van Suikerfabrikanten in Ned.-Indië 34ste Jaargang 1926, 2e Deel, Pabrik Gula Gunungsari beroperasi menggunakan sistem karbonasi. Sistem ini memanfaatkan batuan gamping dari wilayah Puger sebagai bahan dasar. Sementara berdasarkan arsip Van Westersch Grootbedrijf, pabrik ini juga dilengkapi dengan lima penggiling dan mesin pemurnian dengan kapasitas $70 \mathrm{~m}^{3}$. Di bagian tengah pabrik terdapat pembangkit listrik dengan dua turbin yang mengaliri generator (Gambar 3). Apabila satu generator sedang beroperasi maka generator yang lain akan bertindak sebagai cadangan, mengingat pabrik gula ini dirancang agar sanggup beroperasi tanpa berhenti. Ruangan tempat generator pembangkit listrik ini ditempatkan umumnya dikenal sebagai power house atau ruangan penghasil listrik dan umum ditemui di pabrik gula lain di Jawa, seperti pada Pabrik Gula Pangka di Tegal (Daniar 2012). Kemodernan dalam proses pengolahan gula juga terlihat dari penempatan lima mesin boiler yang terelevasi (Gambar 4) sehingga memudahkan alur produksi. Selain itu, digunakan tembaga merah pada alat penggiling dan pengangkut tebu untuk mengurangi tingkat kerusakan mesin dari tetes tebu.

Pabrik gula ini berhenti beroperasi ketika krisis ekonomi melanda dunia pada awal tahun 1930-an. Krisis ekonomi ini tidak hanya memengaruhi Pabrik Gula Gunungsari, akan tetapi juga menghancurkan industri gula di Jawa mengakibatkan banyak pabrik gula tidak lagi sanggup beroperasi (Knight 2013). Krisis ini bahkan membuat salah satu lembaga pemerintah yang bergerak di bidang pemasaran gula merekomendasikan pemberhentian penanaman 
Pemilihan Lokasi Pabrik Gula Gunungsari oleh Handelsvereeniging Amsterdam (HVA): Analisis Keruangan Salah Satu "Sister Factory" Pabrik Gula Jatiroto- Abednego Andhana Prakosajaya, Hot Marangkup Tumpal Sianipar, dan Ayu Nur Widiyastuti (113-124)

Doi: $10.24832 / k e . v 6 i 2.67$

tebu secara keseluruhan. Kendati demikian, hal ini tidak sepenuhnya dilakukan oleh perusahaanperusahaan gula pada masa itu (Hartveld 1996). Krisis penyusutan lahan ini juga berpengaruh pada lahan produktif milik Pabrik Gula Gunungsari yang menyusut menjadi 31 hektare akibat ketidakmampuan menanggung biaya operasional (Nurcahyo 2011). Panen terakhir dilakukan antara tahun 1934-1935 namun hasil panen ini tidak digiling di Pabrik Gula Gunungsari akan tetapi dialihkan menuju Pabrik Gula Semboro yang masih beroperasi pada saat krisis (Nurcahyo 2011). Saat Jepang menduduki Indonesia, Pabrik Gula Gunungsari dan Pabrik Gula Bedadung tidak lagi dapat digunakan karena kerusakan parah yang diderita akibat perang (Widyawati 2018).

\section{Letak dan Tata Ruang Pabrik Gula Gunungsari}

Kompleks Pabrik Gula Gunungsari terletak di Jalan Diponegoro, Desa Kencong, Kecamatan Kencong, Kabupaten Jember dan hanya berjarak satu kilometer ke arah tenggara Alun-Alun Kencong. Saat ini, bangunan utama pabrik untuk produksi gula telah hancur dan beberapa area pabrik ini telah dibangun Pasar Kencong Baru, sehingga bekas bangunan pabrik tidak lagi terlihat. Kendati demikian, terdapat beberapa struktur penyangga pabrik yang masih dapat dijumpai, seperti gudang, tempat pembuangan ampas tebu, bak pendinginan air, bekas kantor pabrik gula, dan beberapa struktur menyerupai bungker. Kejelasan kondisi saat ini yang ditangkap melalui citra satelit dapat dibandingkan dengan peta tahun 1941, seperti yang terlihat pada gambar $5 a$ dan $5 b$. Kotak biru muda merupakan pemukiman pribumi, lingkaran krem merupakan gedung bioskop, kotak biru tua merupakan bangunan pabrik, kotak hijau tua merupakan gedung terbuka pengolahan limbah, lingkaran abu-abu merupakan struktur yang tidak diketahui, kotak kuning merupakan pergudangan, kotak hitam merupakan kantor pabrik, kotak merah merupakan pemukiman pekerja Belanda, lingkaran ungu merupakan rumah administratur, dan kotak hijau merupakan klinik. Apabila melihat gambar udara pada arsip Belanda (Gambar 6), maka dapat diperoleh gambaran mengenai Pabrik Gula Gunungsari beserta lingkungan sekitarnya meskipun secara keseluruhan struktur-struktur ini dalam kondisi yang sangat rawan hancur.
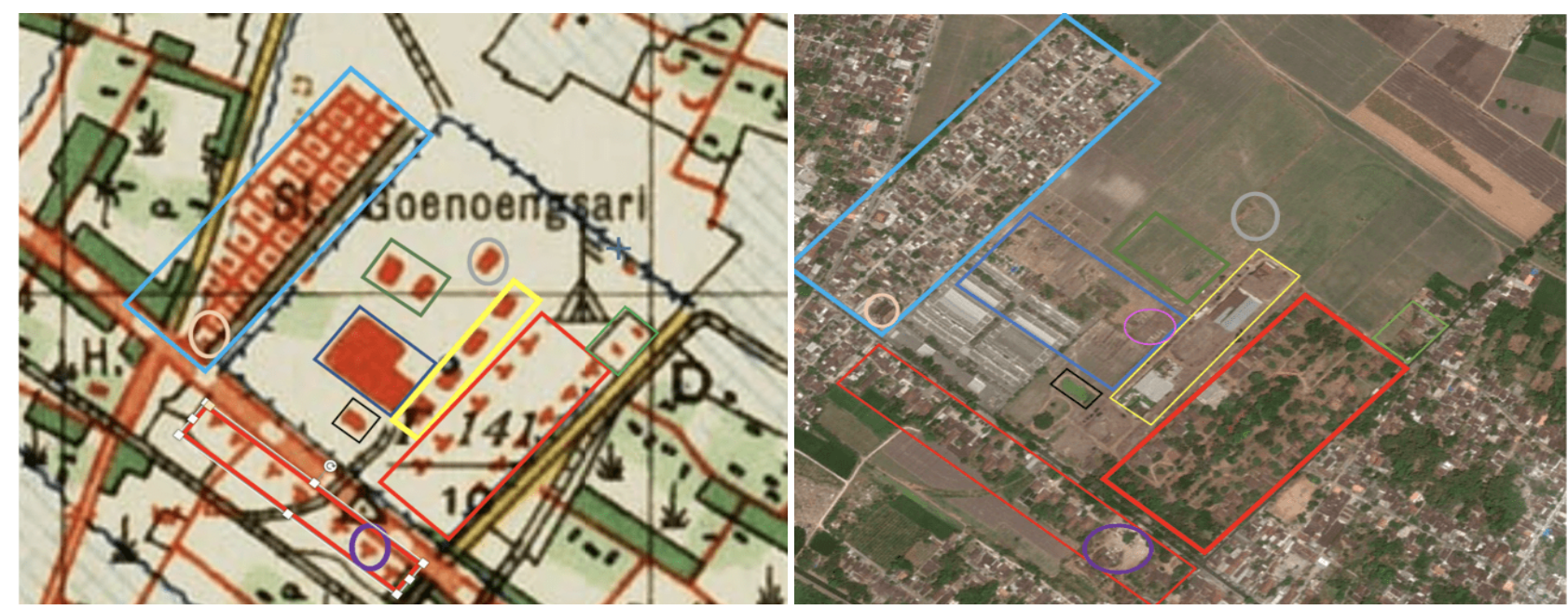

Sumber: http://map s.library.leiden.edu/ dan Google Earth

Gambar 5a dan 5b Peta dari Tahun 1941 (gambar 5a) dan Citra Satelit Bekas Pabrik Gula Saat Ini (gambar 5b) 


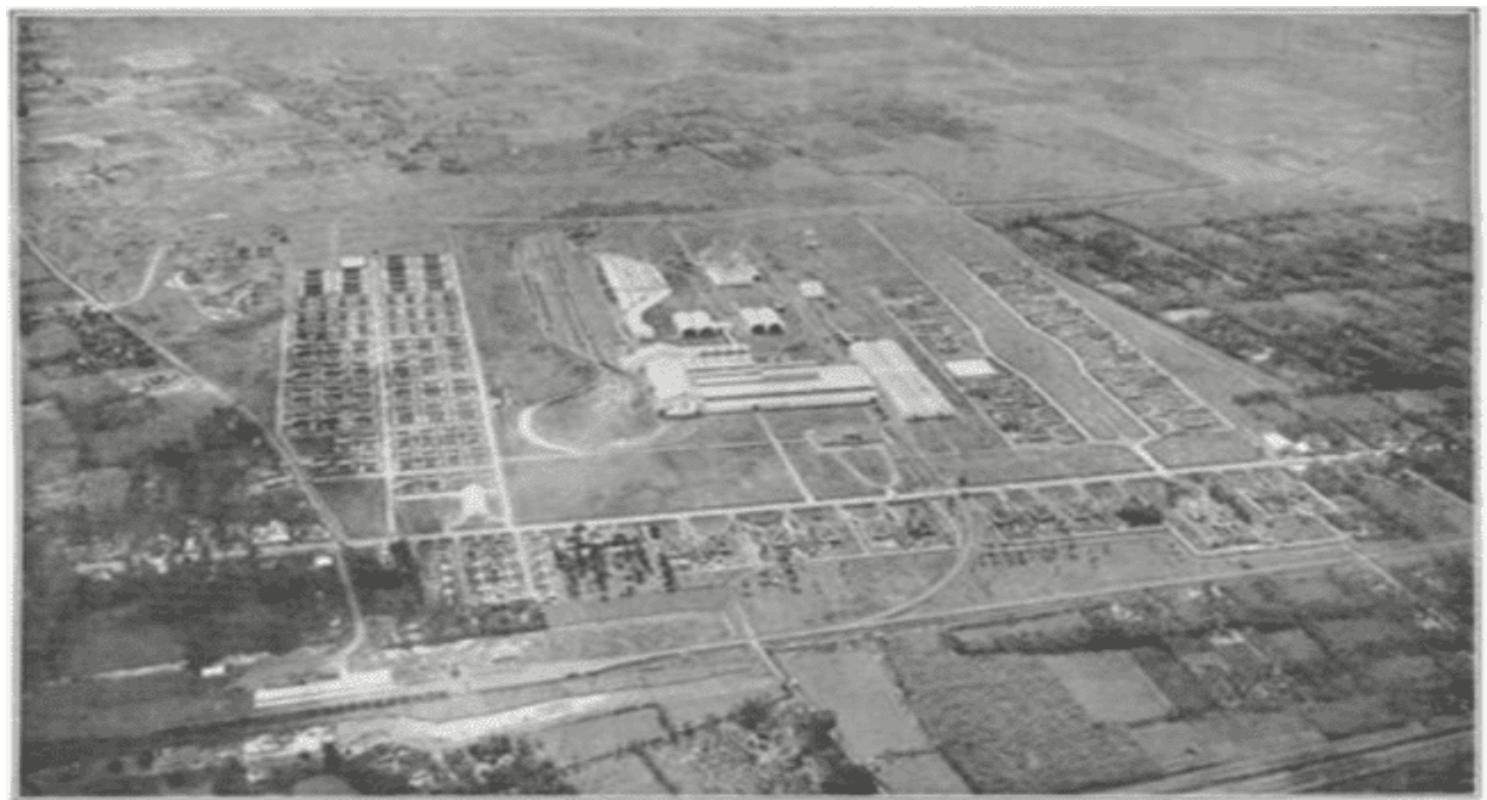

Sumber: Aangeboden Door De Handelsvereeniging "Amsterdam" (HVA) 1 Januari 1929

Gambar 6 Gambar Udara dari Pabrik Gula Gunungsari

Bangunan pabrik memiliki bentuk huruf $\mathrm{L}$ dengan kemungkinan bagian gilingan sebagai bagian yang memanjang di sisi selatan pabrik, sementara bagian pengolahan lainnya terdapat di sisi utara. Pada bagian luar pabrik di antara sisi utara dan selatan terdapat bak pendinginan air yang masih dapat dijumpai hingga sekarang. Kemungkinan bagian gilingan yang terletak di sisi selatan ini didukung dengan keberadaan rel lori di sisi selatan pabrik pada peta tahun 1941. Pada bagian timur pabrik yang dahulunya berseberangan dengan gilingan, terdapat tiga buah struktur gudang yang saat ini masih dapat dijumpai (Gambar 7). Bangunan kantor terletak di sisi selatan pabrik sementara dan saat ini hanya menyisakan dinding sisi timur (Gambar 8). Pada sisi utara pabrik terdapat bekas bangunan terbuka dengan atap yang saat ini hanya menyisakan pilar-pilar. Bangunan ini kemungkinan merupakan tempat pengelolaan limbah semasa beroperasi.

Selain bangunan pabrik, terdapat struktur yang menyerupai bungker berbentuk setengah lingkaran di sisi selatan gudang. Kemungkinan besar struktur ini dibangun pasca Pabrik Gula Gunungsari berhenti beroperasi. Secara resmi, bekas bangunan dan lahan Pabrik Gula Gunungsari dimiliki oleh PT Perkebunan Nusantara XI atau PTPN XI dan berada di bawah pengelolaan Pabrik Gula Semboro. Saat ini, bekas bangunan pabrik difungsikan sebagai tempat pembuangan limbah dari Pabrik Gula Semboro. Sebagian dari lahan yang dimiliki oleh PTPN XI diubah menjadi Pasar
Kencong Baru dan proses pembangunan pasar di atas bekas bangunan pabrik Gula Gunungsari milik PTPN XI ini sempat menjadi sengketa beberapa tahun silam.

Meskipun struktur Pabrik Gula Gunungsari tinggal reruntuhan, pemukiman dan sarana penunjang lainnya masih dapat dijumpai. Umumnya perluasan pemukiman dan pembangunan sarana penunjang pabrik gula merupakan sebuah bukti kedinamisan perkembangan pabrik gula dari satu periode ke periode lainnya (Putra dan Wirasanti 2019). Akan tetapi, dalam kasus Pabrik Gula Gunungsari, singkatnya periode operasional pabrik membuat tidak adanya perluasan, pembangunan pemukiman maupun sarana penunjang. Kompleks pemukiman karyawan Belanda terletak di sisi timur dan selatan pabrik dengan jumlah 35 rumah (Gambar 9). Pemukiman pekerja pribumi terletak di sisi barat pabrik, sehingga pabrik bertindak sebagai pembatas kedua pemukiman ini. Pemukiman di sisi barat dilengkapi dengan bangunan serbaguna yang umum digunakan karyawan untuk berpesta dan berdansa serta sebuah lapangan tenis. Perumahan di sisi barat ini terletak berhadap-hadapan dengan tiga buah jalan yang sejajar, membentang dari timur laut ke barat daya. Perumahan di sisi selatan pabrik dipisahkan oleh jalan raya yang saat ini menjadi Jalan Diponegoro. Rumah administratur pabrik (Gambar 10) terletak di perumahan sisi selatan di mana ujung jalan utama perumahan sisi barat bertemu dengan jalan raya yang membentang dari barat laut ke tenggara. 
Pemilihan Lokasi Pabrik Gula Gunungsari oleh Handelsvereeniging Amsterdam (HVA): Analisis Keruangan Salah Satu "Sister Factory" Pabrik Gula Jatiroto- Abednego Andhana Prakosajaya, Hot Marangkup Tumpal Sianipar, dan Ayu Nur Widiyastuti (113-124)

Doi: $10.24832 / k e . v 6 i 2.67$

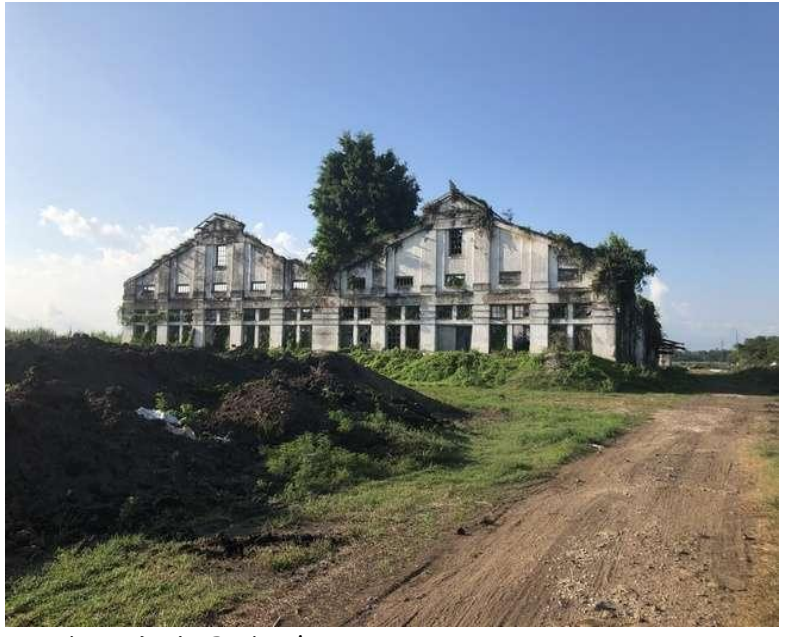

Sumber: Dok. Pribadi

Gambar 7 Gudang di Bagian Timur Pabrik Gula Gunungsari

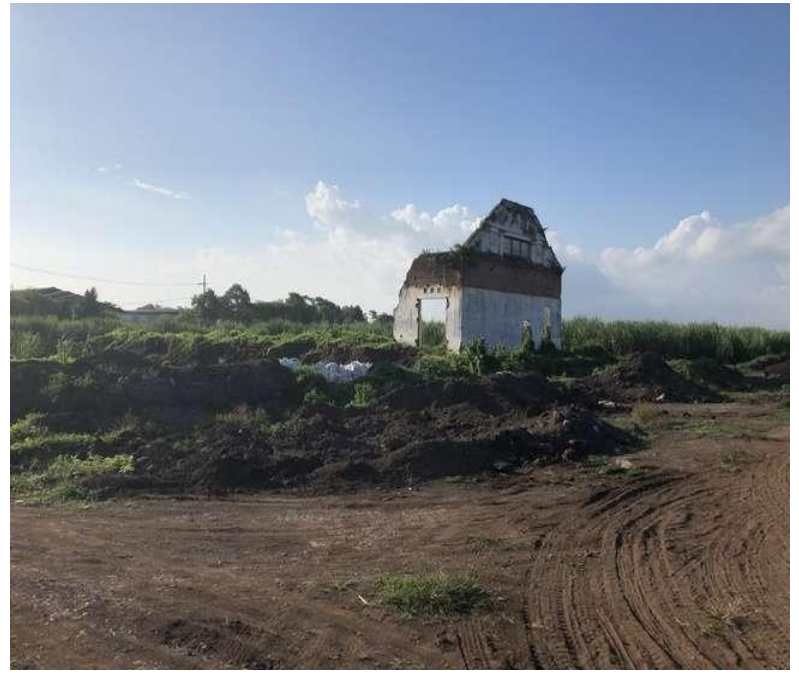

Sumber: Dok. Pribadi

Gambar 8 Bekas Kantor Pabrik Gula Gunungsari yang Hanya Menyisakan Dinding Sisi Timur

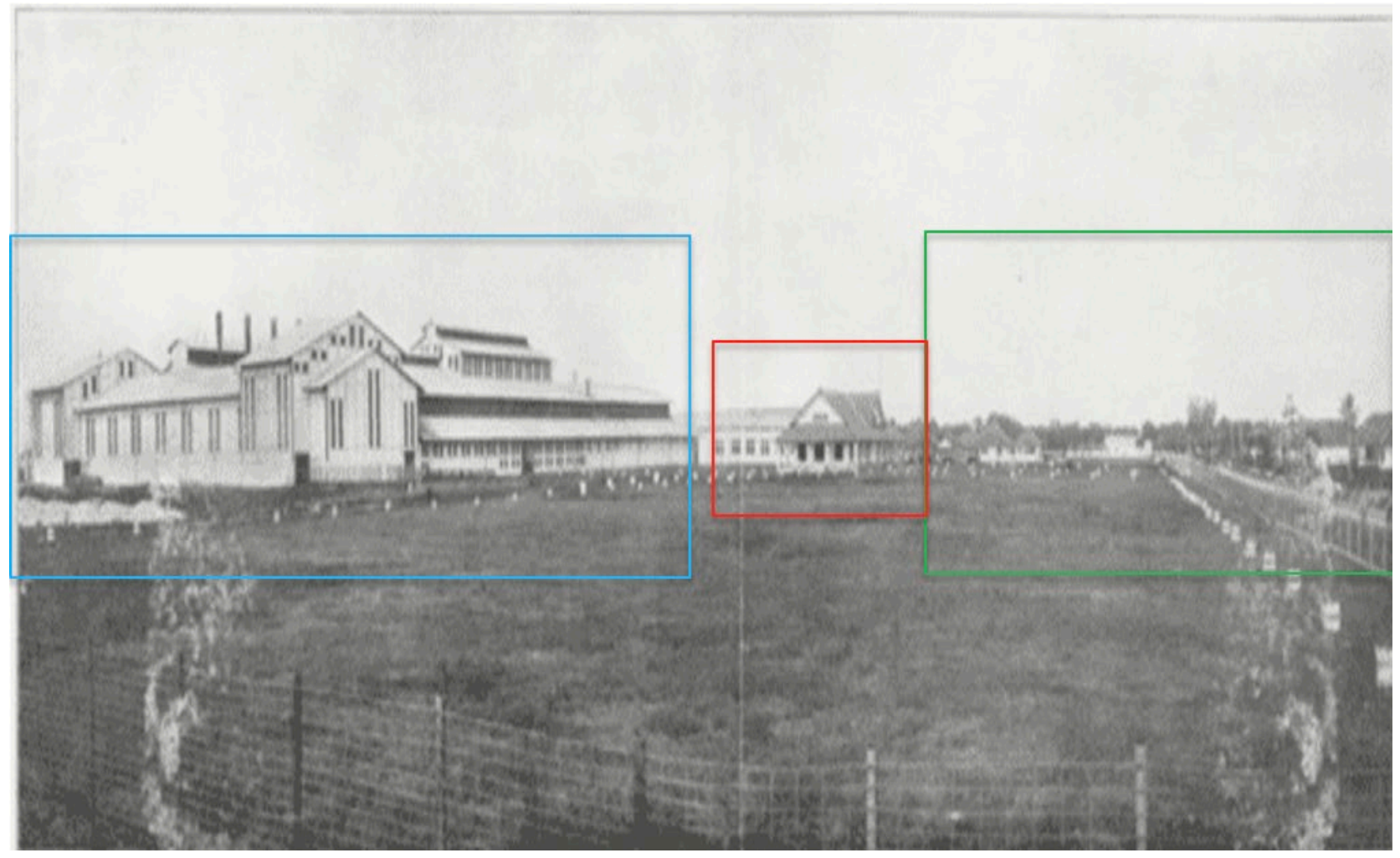

Sumber: Aangeboden Door De Handelsvereeniging "Amsterdam" (HVA) 1 Januari 1929

Gambar 9 Tampak Kantor Pabrik (Kotak Merah) Berada di Sisi Selatan Gedung Pabrik (Kotak Biru), serta Sisi Barat dan Selatan Lingkungan Pabrik di kelilingi oleh Pemukiman Pekerja Belanda (Kotak Hijau) 


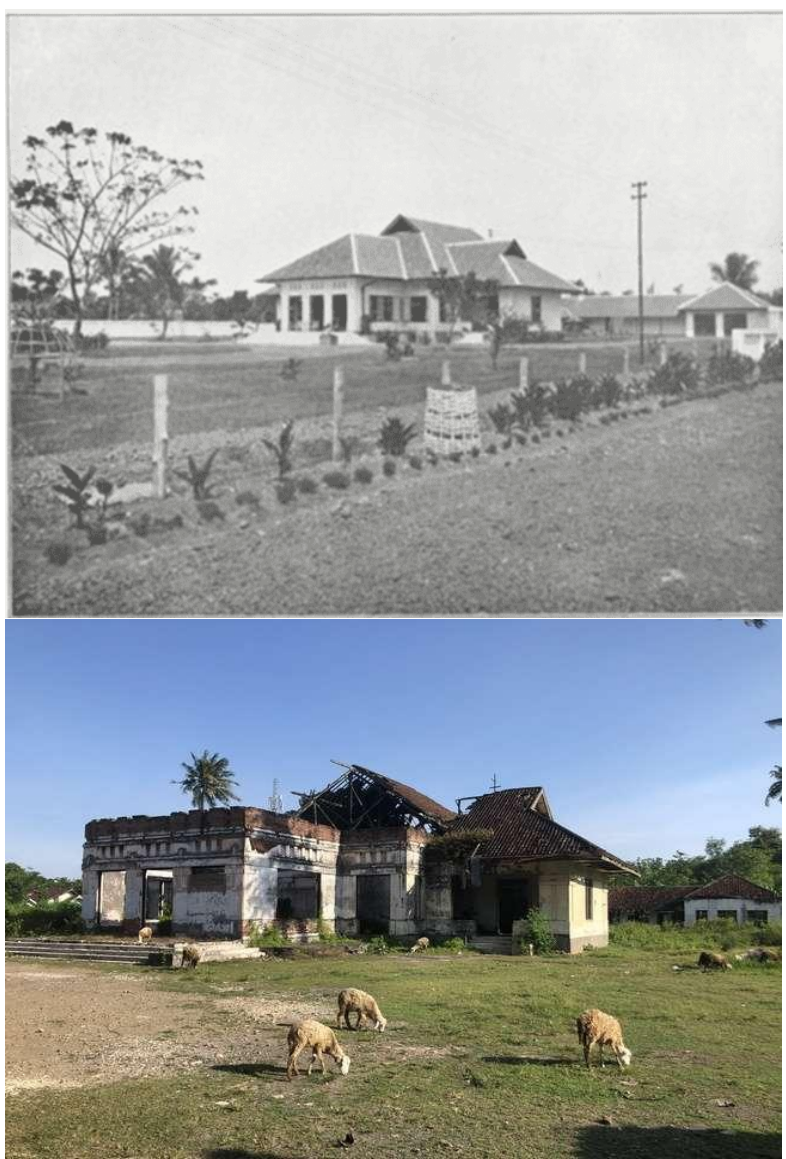

Sumber: Aangeboden Door De Handelsvereeniging

"Amsterdam" (HVA) 1 Januari 1929 dan Dok. Pribadi

Gambar 10 Rumah Administratur Pabrik Gula Gunungsari

Selain perumahan, terdapat gedung yang pada masa operasional pabrik dimanfaatkan sebagai bioskop dan dapat digunakan oleh pekerja pribumi. Gedung ini terletak di sisi barat pabrik atau berdampingan dengan pemukiman pribumi dan terletak di tepi Jalan Diponegoro. Selain itu, juga terdapat klinik yang terletak di bagian utara perumahan sisi timur. Klinik ini tidak hanya dikhususkan untuk pegawai Belanda tetapi juga terbuka untuk pekerja pribumi dan dikelola oleh para mantri dengan dokter yang datang ke klinik satu minggu sekali (Ochsendorf 2018). Adapun klinik serta rumah sakit merupakan sarana pendukung yang umum dijumpai dalam suatu tata ruang pabrik gula pada masa kolonial dan umumnya dikhususkan untuk para pegawai yang bekerja di pabrik gula tersebut (Putra dan Wirasanti 2019). Bangunan tersebut saat ini telah dimanfaatkan sebagai Taman Kanak-kanak Negeri Pembina. Perkampungan pekerja pribumi yang terletak di sisi barat pabrik saat ini masih dihuni dan dikenal dengan istilah Kampung Kamaran (Gambar 11). Toponimi ini berasal dari bentuk rumah yang hanya terdiri atas kamar-kamar. Pembangunan Kampung Kamaran ini menelan biaya 375.000 gulden dan sepenuhnya dibiayai oleh HVA. Kampung Kamaran ini didesain untuk menjadi hunian permanen dan dilengkapi dengan toilet serta pemandian terpusat.

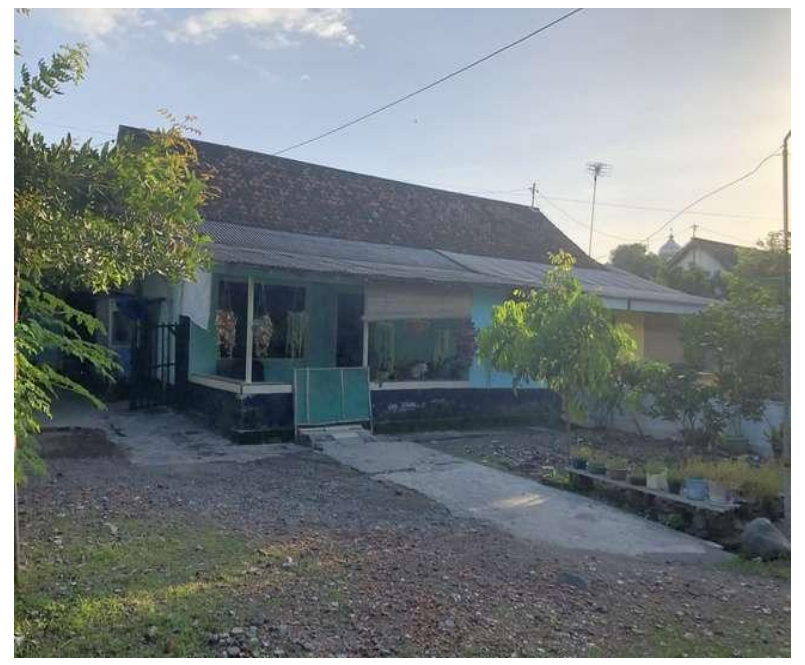

Sumber: Dok. Pribadi

Gambar 11 Beberapa Rumah di Kampung Kamaran Tempat Pekerja Pribumi Tinggal

\section{Analisis Pemilihan Letak Pabrik Gula Gunungsari Oleh HVA}

Dalam konteks kawasan perkebunan gula yang merupakan perkembangan dari Pabrik Gula Jatiroto, Pabrik Gula Gunungsari menempati wilayah yang paling selatan di antara keempat pabrik gula lainnya. Pabrik Gula Jatiroto terletak 17 $\mathrm{km}$ ke arah barat laut, sementara Pabrik Gula Semboro terletak hampir $11 \mathrm{~km}$ ke arah timur laut. (Berdasarkan peta kolonial yang dikaji, letak Pabrik Gula Bedadung tidak lagi diketahui). Letak yang berada paling selatan bila dibandingkan dengan keempat pabrik gula lainnya membuat jarak Pabrik Gula Gunungsari dengan Pantai Selatan Jawa relatif cukup dekat atau hanya $7,13 \mathrm{~km}$ dari bibir pantai. Penempatan Pabrik Gula Gunungsari ini seharusnya tidak terlalu berpengaruh terhadap varietas tanaman tebu yang digunakan. Pabrik gula lain seperti Pabrik Gula Sewugalur memiliki jarak $3,98 \mathrm{~km}$ dari bibir pantai terdekat namun dapat beroperasi dalam jangka waktu yang cukup lama dari tahun 1880-an hingga berhenti beroperasi 1930-an (Suharini 2016). Pemilihan lokasi pabrik gula yang cukup berdekatan dengan pantai selatan ini mempertimbangkan penggunaan gamping 
Pemilihan Lokasi Pabrik Gula Gunungsari oleh Handelsvereeniging Amsterdam (HVA): Analisis Keruangan Salah Satu "Sister Factory" Pabrik Gula Jatiroto- Abednego Andhana Prakosajaya, Hot Marangkup Tumpal Sianipar, dan Ayu Nur Widiyastuti (113-124)

Doi: $10.24832 / k e . v 6 i 2.67$

sebagai bahan penting untuk pengoperasian pabrik.

Pemilihan lokasi pabrik ini relatif menguntungkan, mengingat terdapat Pegunungan Kapur di Puger yang terletak belasan kilometer arah tenggara dari Pabrik Gula Gunungsari (Gambar 12). Dalam hal ini, peletakan Pabrik Gula Gunungsari didasarkan pada efisiensi jarak antara Puger dengan Kencong untuk kemudian difungsikan menjadi titik pengumpulan batu gamping yang juga diperlukan oleh pabrik gula lainnya seperti Pabrik Gula Semboro.
Selain itu, berdasarkan peta Karesidenan Pasuruan tahun 1885 dan peta Karesidenan Besuki pada tahun 1888 yang saling berhubungan, Jalan Diponegoro merupakan satu-satunya penghubung antara Jember yang berada di wilayah Karesidenan Besuki dan Lumajang yang berada di wilayah Karesidenan Pasuruan sebelum dibangun akses baru di utara bersamaan dengan dibangunnya Pabrik Gula Jatiroto. Meskipun bukan merupakan jalan utama, lokasi Kencong sebagai perkampungan cukup strategis di antara jalan penghubung Jember dan Lumajang.

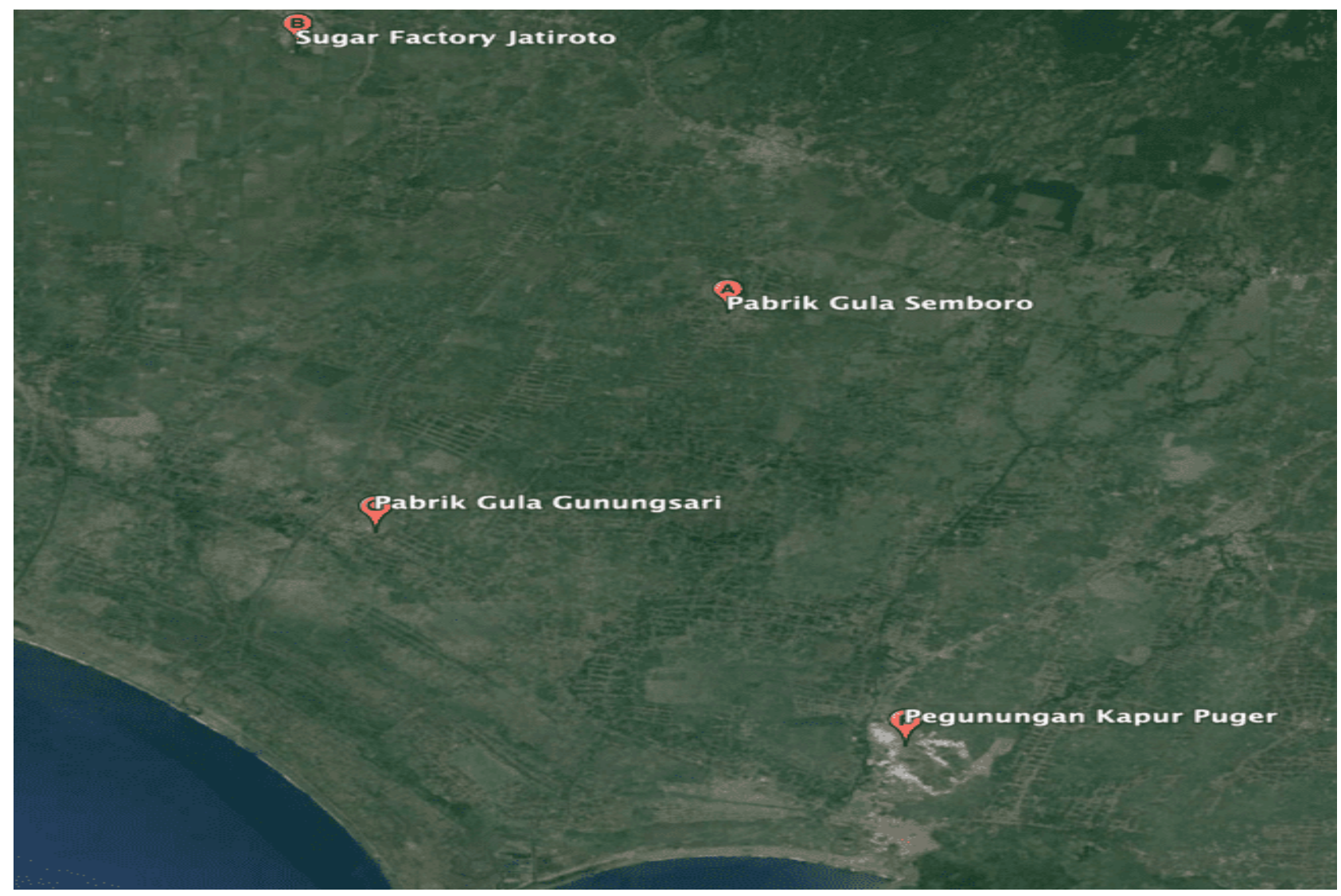

Sumber: Google Earth

Gambar 12 Keletakan Pabrik Gula Gunungsari dengan Pabrik Gula Lain yang dimiliki HVA dan Pegunungan Kapur di Puger

Kondisi tersebut tentu berpengaruh dalam pemilihan lokasi dibangunnya Pabrik Gula Gunungsari. Baik Pabrik Gula Jatiroto, Semboro, maupun Gunungsari memerlukan sistem pengairan yang baik untuk menjamin jalannya operasional pabrik. Pabrik Gula Jatiroto dan Semboro menggunakan aliran irigasi Bondoyudo yang dibangun oleh HVA sebagai sumber pengairan pabrik (Gambar 13). Akan tetapi, sumber air Pabrik Gula Gunungsari berasal dari Sungai Meneng yang berpotongan dengan kanal utama saluran irigasi
Bondoyudo dan terletak satu kilometer dari pabrik. Perbedaan sumber pengairan pabrik Gunungsari dengan kedua pabrik lainnya membuat pabrik ini memiliki ketergantungan tinggi akan debit Sungai Meneng yang merupakan sungai alami. Berbeda dengan aliran irigasi Bondoyudo yang sepenuhnya dibangun dan dapat dikendalikan oleh HVA, aliran Sungai Meneng dapat mengalami pasang-surut meskipun beberapa pintu air telah dibangun pada bagian hulu sungai sebelum memasuki wilayah Kencong (Gambar 14). Kemungkinan kurangnya 
pengairan untuk mendukung beroperasinya pabrik ini didukung oleh cerita turun-temurun warga sekitar yang menyatakan bahwa pabrik ini berhenti beroperasi karena kekurangan air. Krisis kekurangan air sebagai penghasil energi listrik ini diakibatkan oleh penggunaan mesin berkapasitas besar yang memerlukan daya listrik tinggi, sehingga Pabrik Gula Jatiroto sebagai pusat juga mengalami permasalahan serupa (Knight 2013).

Pemilihan lokasi dibangunnya Pabrik Gula Gunungsari sebetulnya tidak didasarkan pada biaya investasi yang rendah. Hal ini mengingat bahwa wilayah sekitar tempat Pabrik Gula Gunungsari berdiri dahulunya adalah rawa yang dibuktikan dengan peta wilayah Kencong tahun 1888 seperti terlihat pada (Gambar 15). Proses pengubahan rawa menjadi lahan produktif ini juga dilakukan saat pembangunan Pabrik Gula Jatiroto dan menelan biaya yang tidak sedikit. Namun, menjadi kebanggaan tersendiri bagi HVA untuk mengubah rawa dan hutan menjadi lahan produktif dengan sistem irigasi yang kompleks (Knight 2013). Pemilihan lokasi rawa ini sesuai dengan rancangan pengembangan kawasan perkebunan Jatiroto yang didasarkan pada sistem pengolahan industri gula di Kuba (Knight 2013). Sistem pengolahan gula memiliki ciri-ciri di bangunnya kawasan perkebunan terpadu dengan lahan yang luas dan jauh dari pemukiman. Tentunya hal ini cukup berbeda dengan pabrik gula di Jawa dan Hindia Belanda pada umumnya yang bergantung pada lingkungan rural sebagai penyedia tenaga kerja. Akan tetapi, HVA tidak menghiraukan peringatan bahwa lahan rawa yang dipilih untuk kawasan industri ini ternyata menghasilkan tebu dengan kandungan gula yang terlalu sedikit (Knight 2013).

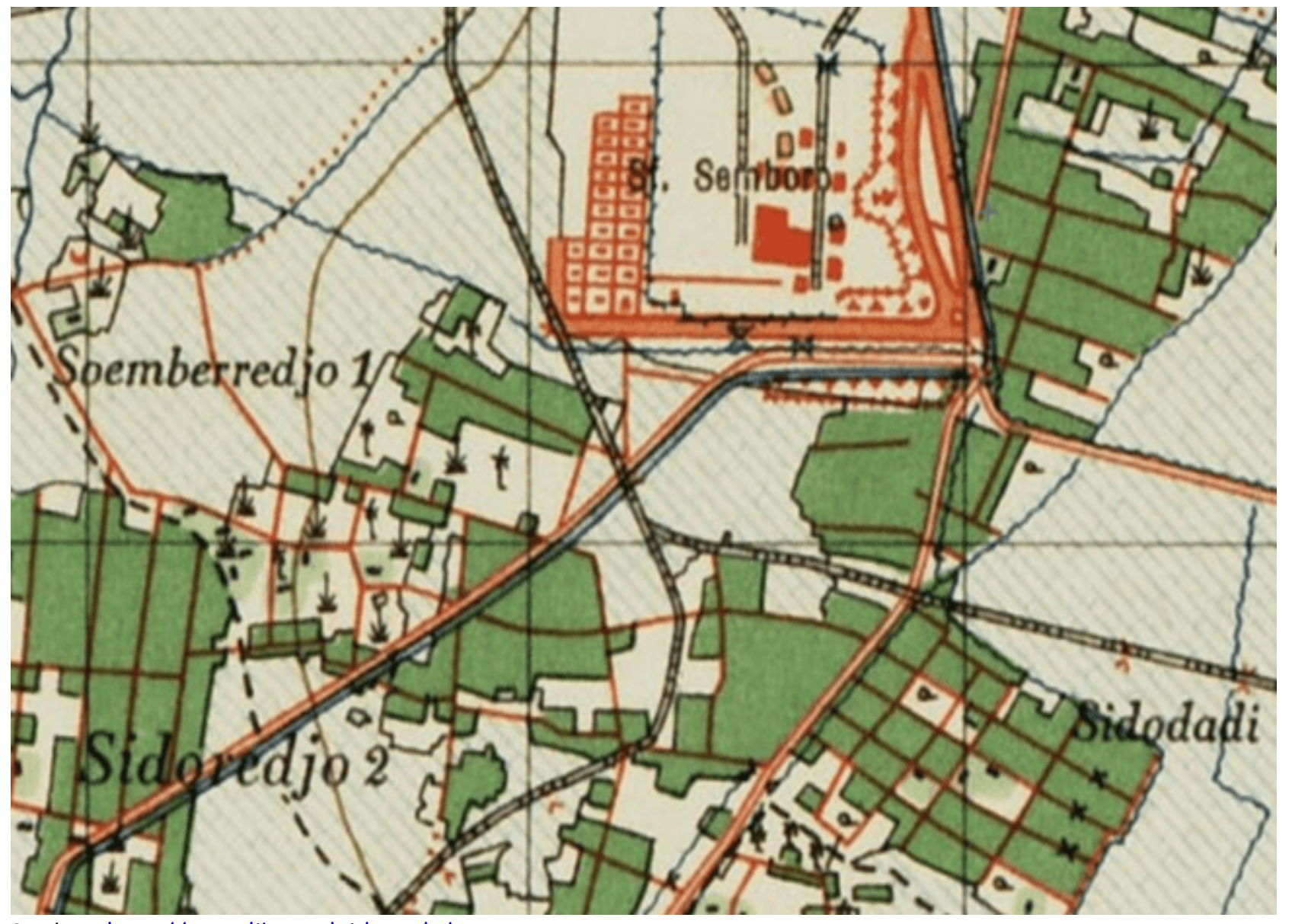

Sumber: http://maps.library.leiden.edu/

Gambar 13 Keletakan Pabrik Gula Semboro yang Berdampingan dengan Kanal Utama Irigasi Bondoyudo di Sebelah Timur Berdasarkan Peta Tahun 1941 
Pemilihan Lokasi Pabrik Gula Gunungsari oleh Handelsvereeniging Amsterdam (HVA): Analisis Keruangan Salah Satu "Sister Factory" Pabrik Gula Jatiroto- Abednego Andhana Prakosajaya, Hot Marangkup Tumpal Sianipar, dan Ayu Nur Widiyastuti (113-124)

Doi: $10.24832 / k e . v 6 i 2.67$

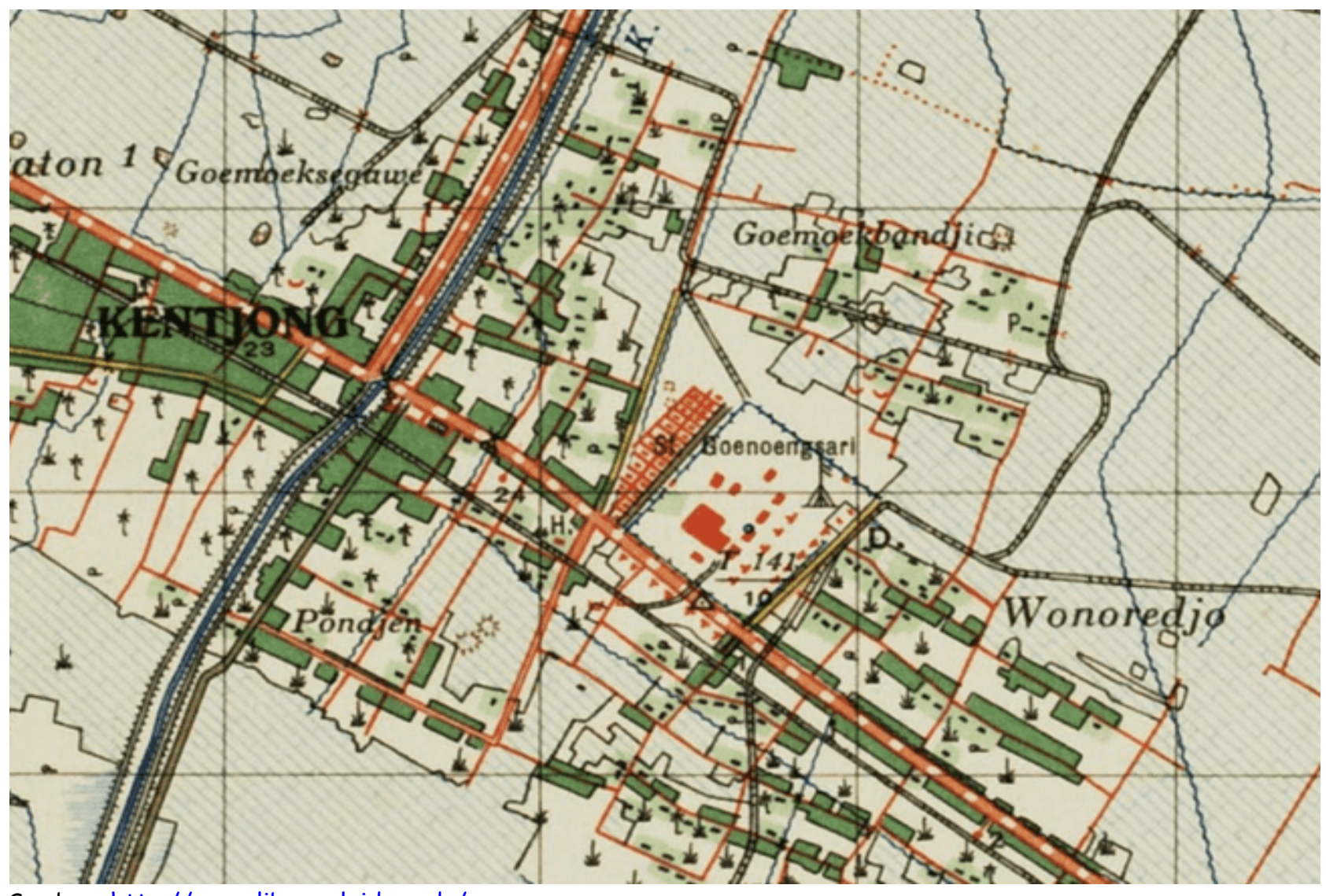

Sumber: http://maps.library.leiden.edu/

Gambar 14 Keletakan Pabrik Gula Gunungsari pada Peta Tahun 1941

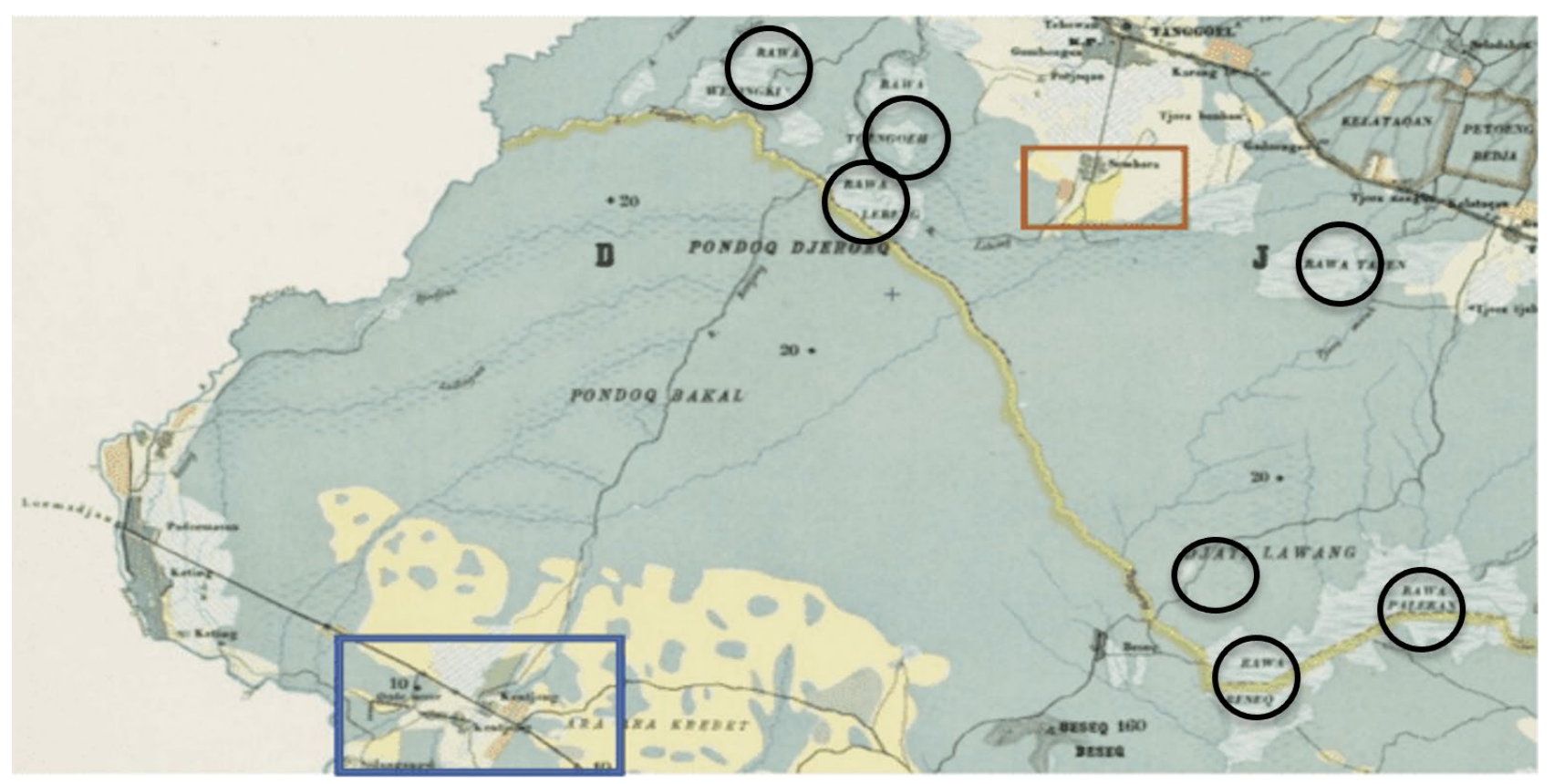

Sumber: http://maps.library.leiden.edu/

Gambar 15 Beberapa Rawa (Lingkaran Hitam) pada Peta Tahun 1888 yang Berada di antara Kencong (Kotak Biru) dan Semboro (Kotak Jingga) Sebelum Pabrik Gula Dibangun

Berbeda dengan pabrik induk Jatiroto yang sepenuhnya dibangun dari rawa maupun pabrik kembarnya di Semboro yang dibangun berdekatan dengan suatu pemukiman, Pabrik Gula Gunungsari 
terletak sangat dekat dengan Kencong yang berdasarkan peta tahun 1888 merupakan suatu pemukiman dengan lingkungan rural yang lebih besar dari Semboro. Pemilihan lokasi yang berdekatan dengan pemukiman Kencong ini memiliki keuntungan dan kerugian. Di satu sisi, Pabrik Gula Gunungsari dapat memanfaatkan masyarakat Kencong untuk memperoleh tenaga kerja tambahan meskipun keberadaan Kampung Kamaran di sisi barat pabrik atau pada sisi yang mengarah ke perkampungan Kencong menandakan bahwa banyak tenaga kerja lokal yang didatangkan dari luar wilayah Kencong. Hal ini dapat meningkatkan efisiensi penggunaan sumber daya manusia apabila dibandingkan dengan Jatiroto maupun Semboro. Jika dipandang secara negatif, lokasi pabrik gula yang terlalu dekat dengan pemukiman dapat menimbulkan berbagai macam konflik yang merugikan pabrik gula itu sendiri.

\section{PENUTUP}

Pabrik Gula Gunungsari dibangun dengan pertimbangan kewilayahan yang sangat bergantung pada investasi yang tinggi. Dilihat dari pemilihan letaknya dengan pabrik gula lain dalam sistem pengelolaan gula di kawasan Jatiroto yang dikuasai oleh HVA, maka Pabrik Gula Gunungsari sebetulnya tidak terlalu efisien mengingat letaknya yang terlalu dekat dengan Pabrik Gula Semboro. Hal ini tidak menjadi permasalahan apabila tuntutan operasional pabrik ini tidak terlalu tinggi. Pabrik Gula Gunungsari sebagai bagian dari sistem perkebunan Jatiroto yang dirancang sesuai dengan sistem pengelolaan di Kuba dilengkapi dengan mesin canggih berkapasitas besar dan memerlukan tenaga ahli dari Eropa dengan gaji yang tinggi (Knight 2013). Pemilihan lokasi pabrik yang tidak mempertimbangkan secara matang pengairan sebagai sumber listrik pabrik tentu menjadi permasalahan besar yang membuat beban operasional dan tanggungan biaya investasi pabrik semakin tinggi. Selain itu, andai kata Pabrik Gula
Gunungsari dan Pabrik Gula Semboro tidak dimiliki oleh satu perusahaan yang sama maka kedekatan lokasi kedua pabrik ini bukan menjadi permasalahan. Hal ini dibuktikan dengan lokasi Pabrik Gula Colomadu yang hanya berjarak dua kilometer dari Pabrik Gula Gembongan namun masih dapat beroperasi dalam jangka waktu yang cukup lama. Mengingat biaya investasi yang tidak terlalu tinggi dan perbedaan kepemilikan, sehingga biaya operasional pabrik tidak harus ditanggung satu perusahaan.

Pada akhirnya ekspektasi dan ambisi yang terlalu besar dari HVA membuat pemilihan letak Pabrik Gula Gunungsari menjadi suatu kelemahan. Pemilihan lokasi pabrik yang berada di sekitaran rawa dan keputusan untuk tidak memanfaatkan tenaga lokal menunjukkan tindakan yang ceroboh dengan harapan yang terlalu optimistik terhadap hasil beroperasinya pabrik. Kelemahan dalam pemilihan lokasi ini berujung pada pemberhentian operasi Pabrik Gula Gunungsari meskipun pabrik kembarnya di Semboro masih terus beroperasi, bahkan saat pabrik ini menghadapi krisis manajemen (Knight 2013) maupun krisis ekonomi yang terjadi pada tahun 1930-an.

\section{UCAPAN TERIMA KASIH}

Penulis mengucapkan banyak terima kasih kepada semua pihak yang telah membantu memberikan saran dan masukannya dalam penulisan artikel ini, yakni kepada Bapak Sektiadi, S.S., M.Hum. selaku dosen Prodi S1 Arkeologi Universitas Gadjah Mada. Penulis juga mengucapkan terima kasih kepada Wenseslaus Kusumawardhana, Graneta Arum Ade Pasa, dan Raafiansyah Ghani Mahendra yang telah memberi masukan dalam bidang kebahasaan pada tulisan ini. Terima kasih juga penulis sampaikan kepada Punky Budi Cahyono atas bantuannya dalam menyediakan informasi yang sangat membantu dalam penyusunan tulisan ini.

\section{DAFTAR PUSTAKA}

Handels Vereeniging Amsterdam. 1929. Aangeboden Door De Handels Vereeniging "Amsterdam" (HVA) 1 Januari 1929.
Amsterdam: Handels Vereeniging "Amsterdam"

Algemenen Syndicaat van Suikerfabrikanten in Ned.-Indië. 1926. Archief voor de 
Pemilihan Lokasi Pabrik Gula Gunungsari oleh Handelsvereeniging Amsterdam (HVA): Analisis Keruangan Salah Satu "Sister Factory" Pabrik Gula Jatiroto- Abednego Andhana Prakosajaya, Hot Marangkup Tumpal Sianipar, dan Ayu Nur

Suikerindustrie in Nederlandsch-Indië: Orgaan van het Algemenen Syndicaat van Suikerfabrikanten in Ned.-Indië 34ste Jaargang 1926, 2e Deel. Surabaya: Algemenen Syndicaat van Suikerfabrikanten in Ned.-Indië (Soerabaia)

Daniar, D. 2012. Depok "Pabrik Gula Pangka, Tegal, Jawa Tengah pada Abad XIX Kajian Arkeologi Industri". Skripsi. Depok: Fakultas IImu Pengetahuan Budaya, Universitas Indonesia.

Dofi. 2016. "Pabrik Gua Jatiroto dan Pencemaran Lingkungan di Desa Sidorejo, Kecamatan Rowokangkung, Kabupaten Lumajang Tahun 1989-2010". Skripsi. Jember: Fakultas Ilmu Budaya, Universitas Jember.

Ginaris, Lengkong Sanggar. 2019. "Pergeseran Letak Permakaman Belanda di Kota Surabaya dari Abad 18 hingga Awal Abad 20." Berkala Arkeologi 39(2): 183-200.

Hartveld, Aard J. 1996. Raising Cane: Linkages, Organizations and Negotiations in Malang's Sugar Industry, East Java. Utrecht: Uitgeverij Eburon.

Knight, G. Roger. 2013. Commodities and Colonialism: The Big Story of Big Sugar in Indonesia, 1880-1942. Leiden: Brill.

Nurcahyo, Abraha. 2011. "Tata Kelola Industri Gula di Situbondo Masa Kolonial dan Kebijakan Pergulaan Masa Kini”. Agastya 01(02): 174202.

Ochsendorf, Frank. 2018. "Colonial Corporate Social Responsibility: Company Healthcare in Java, East Sumatra and Belitung, 19101940“. Lembaran Sejarah 14(1): 83-97.

Putra, Oktavian Ardana dan Niken Wirasanti. 2019. "Tata Ruang dan Perkembangan Kompleks Pabrik Gula Tanjung Tirto Tahun 1920-1944, Kabupaten Sleman". Panalungtik 2(2):139154.

Soerabaiasch Handelsblad. 1927. Van Westersch Grootbedrij: Overdruk eener serie artikelen uit het Soerabaiasch Handelsblad van 30,31 Mei, 1, 2, en 3 Juni 1927. Surabaya: Soerabaiasch Handelsblad

Suharini, Th. Sri dan Ign. Eka Hadiyanta. 2016. "Citra Indis di Tengah-Tengah Pedesaan Sewugalur". Buletin Narasimha 09(IX): 4053.

Sukendar, Haris. 1999. Metode Penelitian Arkeologi. Jakarta: Pusat Penelitian Arkeologi Nasional.

Widyawati, M. P. 2018. "Mitos dalam Ritual Petik Tebu Manten di Pabrik Gula Semboro". Skripsi. Jember: Fakultas Keguruan dan IImu Pendidikan, Universitas Jember. 